\title{
PHYTOCHEMICAL SCREENING AND ANTIOXIDANT POTENTIAL OF ANACARDIUM OCCIDENTALE, ACHYRANTHES ASPERA, AND AEGLE MARMELOS
}

\author{
BRIJYOG $^{1,2 *}$, LALITESHWAR PRATAP SINGH ${ }^{1}$, SUSHIL KUMAR ${ }^{2}$, SHWETA VERMA ${ }^{2}$
}

${ }^{1}$ Department of Pharmacy, Institute of Pharmacy, Harish Chandra P.G. College Varanasi-221002, Uttar Pradesh, India. ${ }^{2}$ Department of Pharmacy, Faculty of Pharmacy, IFTM University, Moradabad, Uttar Pradesh, India. Email: r.brijyog@rediffmail.com

Received: 24 May 2019, Revised and Accepted: 25 June 2019

\section{ABSTRACT}

Objective: Anacardium occidentale, Achyranthes aspera, and Aegle marmelos are the common plants found in North and South India. The present study identifies the active phytochemicals and antioxidant properties in various extracts derived from dried bark, whole aerial parts, and leaves of the above plants.

Materials and Methods: Phytochemical screening included extracts of pet ether, hydroalcoholic, and aqueous. The antioxidant activity was determined by measuring total phenolic contents (TPC), 1,1-diphenyl-2-picrylhydrazyl (DPPH) radical scavenging activity (RSA), and total flavonoid content (TFC)

Results: The phytochemical screening of $A$. occidentale, $A$. aspera, and $A$. marmelos of dried bark, whole aerial parts, and leaves revealed the presence of flavonoids, phenols, tannins, and proteins. It also contains alkaloids and glycosides. Hydroalcoholic extract of $A$. occidentale, $A$. aspera, and $A$. marmelos showed highest TPC $0.125 \mathrm{mg} / \mathrm{g}, 0.256 \mathrm{mg} / \mathrm{g}$, and $0.254 \mathrm{mg} / \mathrm{g}$, respectively. TFCs $0.094 \mathrm{mg} / \mathrm{g}, 0.145 \mathrm{mg} / \mathrm{g}$, and $0.121 \mathrm{mg} / \mathrm{g}$ and highest DPPH RSA with the half maximal inhibitory concentration of $125 \mu \mathrm{g} / \mathrm{mL}, 105.58 \mu \mathrm{g} / \mathrm{mL}$, and $98.89 \mu \mathrm{g} / \mathrm{mL}$ compare to the standard ascorbic acid of $21.65 \mu \mathrm{g} / \mathrm{mL}$.

Conclusion: This study showed that the hydroalcoholic extract of $A$. occidentale, A. aspera, and A. marmelos is potential source of natural antioxidants.

Keywords: Antioxidant activity, Flavonoids, Phenols, Anacardium occidentale, Achyranthes aspera, Aegle marmelos.

(C) 2019 The Authors. Published by Innovare Academic Sciences Pvt Ltd. This is an open access article under the CC BY license (http://creativecommons. org/licenses/by/4. 0/) DOI: http://dx.doi.org/10.22159/ajpcr.2019.v12i8.34147

\section{INTRODUCTION}

The matter of proper identification and appropriate quality that is lack of adulteration, sophistication, or substitution is an extremely important one in the field of herbal medicine. Nowadays, widely used herbs were once the subject of official monographs of the United States Pharmacopeia and the National Formulary. These monographs established legal standard of identity and subject to the limitations of the methods, period, and quality of the herbal drugs.

The basis of standardized extract gives a solid platform for scientific validation of herbals. Plant materials isolated from them show a substantial proportion of world drug market and globally recognized the guidelines for the assessment of quality are necessary. The quality of medicinal plant for therapeutic purpose must be very high. However, it is very difficult to assay for specific chemical entity provided that the bioactive ingredient is unknown [1,2].

Plants are the potential source of natural antioxidants. Natural antioxidants or phytochemical antioxidants are the secondary metabolites of plants [3]. Plant-derived antioxidants have received greater attention since they act as radical scavengers. To the best of our knowledge, no in vitro antioxidant assay of Anacardium occidentale, Achyranthes aspera, and Aegle marmelos has been reported. Therefore, the study was aimed to determine total phenolic and flavonoid contents and evaluate the antioxidant activity of $A$. occidentale, A. aspera, and A. marmelos.

\section{MATERIALS AND METHODS}

Chemicals and reagents

All the chemicals used were of analytical grade. The chemicals were purchased from Sigma-Aldrich, Bangalore, Global Chemie (India), and Qualikems (India). Sterile distilled water was used, whenever required for the experiment.

\section{Plant material}

A. occidentale, A. aspera, and A. marmelos were collected in August 2016, from the Vindhya Herbal Garden, Bhopal, Madhya Pradesh. The plant material was authenticated and confirmed by Dr. Suman Trivedi, Professor, Department of Botany, Government Maharani Laxmi Bai Girls Postgraduate College, Bhopal, and voucher specimen was deposited as herbarium at the Department of Botany. The collected plant materials were air-dried in dark room at $20^{\circ} \mathrm{C}$. Dried plant parts were cut into small pieces and stored in tight seal light-resistant containers until needed.

\section{Preparation of plant extracts}

The preparation of plant extracts was done as per standard protocol. Transferred $10 \mathrm{~g}$ of plant extract to dark color flask and mixed $200 \mathrm{~mL}$ of solvents petroleum ether, hydroalcoholic, and aqueous, extract was stored at room temperature. After $24 \mathrm{~h}$, infusions were filtered through Whatman filter paper and residue was reextracted with equal volume of solvents. After $48 \mathrm{~h}$, the process was repeated. Combined supernatants were evaporated to dryness under vacuum at $40^{\circ} \mathrm{C}$ using rotary evaporator. The obtained extracts were kept in sterile sample tubes and stored in a refrigerator at $4^{\circ} \mathrm{C}[4]$.

\section{Total phenolic contents (TPC) determination}

Folin-Ciocalteu method was used for the determination of the TPC of the plant extracts using gallic acid as an internal standard with slight modification as previously reported [5]. About $1 \mathrm{~mL}$ of the extract $(1 \mathrm{mg} / \mathrm{mL})$ was mixed with $9 \mathrm{~mL}$ of distilled water in a $25 \mathrm{~mL}$ volumetric flask. Two and half milliliter $(2.5 \mathrm{~mL})$ of a 10 -fold dilute Folin-Ciocalteu phenol reagent (1:10) was added. After $5 \mathrm{~min}, 10 \mathrm{~mL}$ of $7 \% \mathrm{Na}_{2} \mathrm{CO}_{3}$ solution was added to the mixture and made up to the mark with distilled water. The mixture was incubated for $90 \mathrm{~min}$ at room temperature. A set of standard solutions of gallic acid was prepared in the same manner as described for the extracts. The absorbance of the 
extracts and standard solutions were measured against the reagent blank at $750 \mathrm{~nm}$ with an ultraviolet (UV)/visible spectrophotometer (UV-1800, Shimadzu, Japan). The TPC was determined from the calibration curve and expressed as milligram of gallic acid equivalent (GAE) per gram of the extracts [6]. The determination of the total phenolic in the extract was carried out in triplicate.

\section{Determination of total flavonoid content (TFC)}

Aluminum-chloride colorimetric assay was used to determine the TFC in the extracts as previously reported [7]. About $1 \mathrm{~mL}$ of the extract $(1 \mathrm{mg} / \mathrm{mL})$ was mixed with $4 \mathrm{~mL}$ of distilled water in a $10 \mathrm{~mL}$ volumetric flask. About $0.30 \mathrm{~mL}$ of $5 \%$ sodium nitrite was added to the flask. After $5 \mathrm{~min}, 0.30 \mathrm{~mL}$ of $10 \% \mathrm{AlCl}_{3}$ solution was added to the mixture, followed by addition of $2 \mathrm{~mL}$ of $1 \mathrm{M} \mathrm{NaOH}$ after another $5 \mathrm{~min}$ and diluted to the mark with distilled water. A set of standard solutions of quercetin was prepared in the same manner as described for the extracts. The absorbances of the extracts and standard solutions were measured against the reagent blank at $510 \mathrm{~nm}$ with a UV/visible spectrophotometer. The TFC was determined from the calibration curve and expressed as milligram of quercetin equivalent (QE) per gram of extracts [8]. The determinations of total flavonoid in the extracts and standards were carried out in triplicates.

\section{Qualitative phytochemical analysis of the extracts}

Phytochemical analysis of the plant extracts was done to determine the presence of flavonoids, phenol, protein, carbohydrate, alkaloid, and glycoside according to standard methods [9].

\section{Determination of antioxidant capacity}

The antioxidant capacities of the plants of different extract were studied by the evaluation of the free radical-scavenging effect on the 1,1-diphenyl-2-picrylhydrazyl (DPPH) by the modified method [10]. Various concentrations $(20-100 \mu \mathrm{g} / \mathrm{ml})$ of plant extracts $(0.3 \mathrm{~mL})$ were mixed with $2.7 \mathrm{~mL}$ of appropriate solvent (methanol) containing DPPH radical $(0.1 \mathrm{mM})$. The radical stock solution was prepared fresh daily. Ascorbic acid was used as standard in $20-100 \mu \mathrm{g} / \mathrm{mL}$ solution. The mixture was shaken vigorously and allowed to stand at room temperature in the dark for $60 \mathrm{~min}$. The decrease in absorbance of the resulting solutions was monitored at $517 \mathrm{~nm}$. The radical scavenging activity (RSA) was calculated as a percentage of DPPH discoloration, using the equation: $\% \mathrm{RSA}=\left(\left[\mathrm{A}_{\mathrm{DPPH}}-\mathrm{As} / \mathrm{A}_{\mathrm{DPPH}}\right] \times 100\right)[11]$
Where, As=Absorbance of the solution when the sample extracts were added at a particular level and $\mathrm{A}_{\mathrm{DPPH}}=$ Absorbance of DPPH radical solution. All determinations were performed in triplicate. The half maximal inhibitory concentration $\left(\mathrm{IC}_{50}\right.$ ) was calculated as the amount of antioxidants present in the sample necessary to reduce the initial DPPH concentration by $50 \%$.

\section{Statistical analysis}

All experimental measurements were carried out in triplicate and are expressed as average of three analyses \pm standard deviation. The direction and magnitude of correlation between variables was done using analysis of variance (ANOVA) and quantified by the correlation factor.

\section{RESULTS}

A small portion of the dried extracts was subjected to the phytochemical test identification of carbohydrates, alkaloids, steroids, glycosides, tannins, saponins, flavonoids, proteins, and starch separately for extracts of all samples. Small amount of each extract was suitably centrifuged into the sterile distilled water to make the concentration of $1 \mathrm{mg} / \mathrm{ml}$. The outcomes of the results are discussed in Tables 1-3.

From the results obtained, it is clear that A. occidentale, A. marmelos, and $A$. aspera hydroalcoholic extract shows the presence of protein, phenol, amino acid, steroid, and flavonoids. Flavonoids and phenol are the phytochemicals that are present in all the hydroalcoholic extracts. Hydroalcoholic extracts of A. occidentale, A. marmelos, and A. aspera were found highly rich in flavonoids and phenols.

\section{TPC estimation}

Phenolic compounds are a class of antioxidant agents which act as free radical terminators and their bioactivities may be related to their abilities to chelate metals, inhibit lipoxygenase, and scavenge free radicals. The amount of total phenol was determined with the FolinCiocalteu reagent.

The content of TPC was expressed as mg/g of GAE of dry extract sample using the equation obtained from the calibration curve: $\mathrm{Y}=0.038 \mathrm{X}+0.001, \mathrm{R}^{2}=0.997$, where $\mathrm{X}$ is the absorbance and $\mathrm{Y}$ is the GAE.

Gallic acid was used as a standard compound and the total phenols were expressed as $\mathrm{mg} / \mathrm{g}$ GAE using the standard curve equation: $\mathrm{Y}=0.038 \mathrm{X}+0.001, \mathrm{R}^{2}=0.997$, where $\mathrm{X}$ is absorbance at $750 \mathrm{~nm}$ and

Table 1: Phytochemical constituents of Aegle marmelos. " + " indicates, presence; and " - " indicates, absent

\begin{tabular}{|c|c|c|c|c|c|c|c|c|c|}
\hline Extracts & Alkaloids & Glycosides & $\begin{array}{l}\text { Phenols/ } \\
\text { tannins }\end{array}$ & Flavonoids & Saponins & Carbohydrates & Fats and oil & Steroids & Proteins \\
\hline Hydroalcoholic & + & + & + & + & - & + & - & + & + \\
\hline Aqueous & - & + & + & + & - & + & - & - & + \\
\hline Pet ether & - & - & - & - & - & - & + & - & - \\
\hline
\end{tabular}

Table 2: Phytochemical constituents of Achyranthes aspera. " + " indicates, presence; and " - " indicates, absent

\begin{tabular}{llllllllll}
\hline Extracts & Alkaloids & Glycosides & $\begin{array}{l}\text { Phenols/ } \\
\text { tannins }\end{array}$ & Flavonoids & Saponins & Carbohydrates & Fats and oil & Steroids & Proteins \\
\hline Hydroalcoholic & + & + & + & + & + & + & + & - & + \\
Aqueous & - & + & + & + & + & + & - & - & - \\
Pet ether & - & - & - & - & - & - & + & - & - \\
\hline
\end{tabular}

Table 3: Phytochemical constituents of Anacardium occidentale. " + " indicates, presence; and " - " indicates, absent

\begin{tabular}{llllllllll}
\hline Extracts & Alkaloids & Glycosides & $\begin{array}{l}\text { Phenols/ } \\
\text { tannins }\end{array}$ & Flavonoids & Saponins & Carbohydrates & Fats and oil & Steroids & Proteins \\
\hline Hydroalcoholic & + & + & + & + & - & + & - & + & + \\
Aqueous & + & - & + & + & - & + & - & + & + \\
Pet ether & - & - & - & - & - & - & + & - & - \\
\hline
\end{tabular}


$\mathrm{Y}$ is TPC in the extracts of A. occidentale, A. marmelos, and A. aspera expressed in $\mathrm{mg} / \mathrm{g}$. Table 4 shows the variation of mean absorbance with concentration of gallic acid and shows the calibration curve of standard gallic acid. The contents of total phenols that were measured by Folin-Ciocalteu reagent in terms of GAE.

\section{TFC estimation}

TFC was calculated as QE $(\mathrm{mg} / \mathrm{g})$ using the equation based on the calibration curve: $Y=0.041 \mathrm{X}+0.022, \mathrm{R}^{2}=0.995$, where $\mathrm{X}$ is the absorbance and $\mathrm{Y}$ is the QE. Flavonoids as one of the most diverse and widespread group of natural compounds are probably the most important natural phytoconstituents.

The amount of total flavonoids was determined with the quercetin. Quercetin was used as a standard compound and the total flavonoids were expressed as $\mathrm{mg} / \mathrm{g} Q \mathrm{QE}$ using the standard curve equation: $\mathrm{Y}=0.041 \mathrm{X}+0.022$, $\mathrm{R}^{2}=0.995$, where $\mathrm{Y}$ is absorbance at $510 \mathrm{~nm}$ and $\mathrm{X}$ is TFC in the extracts of A. occidentale, A. marmelos, and A. aspera expressed in mg/g. Table 5 shows the variation of mean absorbance value with different concentration of quercetin reagent and shows the calibration curve of quercetin. The contents of total flavonoids were measured by $\mathrm{AlCl}_{3}$ reagent in terms of $\mathrm{QE}$.

The results obtained from the present study showed that the hydroalcoholic extracts of A. occidentale, A. marmelos, and A. aspera which contains highest amount of flavonoids and phenolic compounds, thus can be used to explore new drugs.

\section{Antioxidant activity of hydroalcoholic extract}

DPPH scavenging activity is being used by various researchers. It is very easy and reliable parameter for screening the in vitro antioxidant activity of plant extracts. DPPH is a stable free radical and accepts an electron to become a stable diamagnetic molecule. The absorption maximum of a stable DPPH radical in methanol was at $517 \mathrm{~nm}$ in UV spectrophotometer. It was observed that with the increase of concentration, there is decrease of absorbance value. The decrease in absorbance of DPPH radical caused by antioxidants, due to the reaction between antioxidants molecules and radical, progresses, which results in the scavenging of the radical by electron donation.

Table 4: Preparation of gallic acid calibration curve

\begin{tabular}{lll}
\hline S. No. & Concentration $(\boldsymbol{\mu g} / \mathbf{m l})$ & $\begin{array}{l}\text { Absorbance (Mean) } \boldsymbol{\lambda} \\
\mathbf{m a x}=\mathbf{7 5 0} \mathbf{~ n m}\end{array}$ \\
\hline 1 & 1 & 0.041 \\
2 & 2 & 0.073 \\
3 & 3 & 0.115 \\
4 & 4 & 0.154 \\
5 & 5 & 0.210 \\
6 & 6 & 0.231 \\
7 & 7 & 0.273 \\
8 & 8 & 0.301 \\
9 & 9 & 0.342 \\
10 & 10 & 0.389 \\
\hline
\end{tabular}

Table 5: Preparation of quercetin calibration curve

\begin{tabular}{lll}
\hline S. No. & Concentration $(\boldsymbol{\mu g} / \mathbf{m L})$ & $\begin{array}{l}\text { Absorbance (Mean) } \boldsymbol{\lambda} \\
\mathbf{m a x}=\mathbf{5 1 0} \mathbf{~ n m}\end{array}$ \\
\hline 1 & 1 & 0.071 \\
2 & 2 & 0.115 \\
3 & 3 & 0.155 \\
4 & 4 & 0.195 \\
5 & 5 & 0.235 \\
6 & 6 & 0.275 \\
7 & 7 & 0.312 \\
8 & 8 & 0.351 \\
9 & 9 & 0.391 \\
10 & 10 & 0.438 \\
\hline
\end{tabular}

The percentage of different concentration of standard ascorbic acid and A. occidentale, A. marmelos, and A. aspera is shown in Table 9.

$\mathrm{IC}_{50}$ for standard ascorbic acid was found to be $21.65 \mu \mathrm{g} / \mathrm{ml}$ and for hydroalcoholic extract of A. occidentale, A. marmelos, and A. aspera was found to be $125 \mu \mathrm{g} / \mathrm{mL}, 98.89 \mu \mathrm{g} / \mathrm{mL}$, and $105.58 \mu \mathrm{g} / \mathrm{mL}$, respectively. Thus, the antioxidant activity of sample was less than that of standard ascorbic acid.

Results are given in mean of triplicate. A. aspera extracts have high flavonoid/phenolics ratio, indicating that the extracts have high flavonoid content. The high antioxidant activity with these extracts due to the presence of phenol and flavonoid which are known to inhibit free radicals. The observed antioxidant activity could be attributed to these metabolites [12].

Free radicals are the cause for several major disorders. Hence, evaluation of antioxidant activity in plants could result in the discovery of natural antioxidants with pharmacological and food value. Therefore, these observations can be used in pharmaceutical to explore new drugs [Tables 6-8].

\section{DISCUSSION}

Phytochemical screening is done for analyzing secondary metabolites, which are responsible for curing ailments. Phytochemical screening of the extracts was investigated according to the standard procedure. The petroleum ether, hydroalcoholic, and aqueous extract of bark of A. occidentale and leaves of $A$. marmelos and whole aerial plant material of $A$. aspera were investigated to preliminary phytochemical screening for the presence of various phytoconstituents, i.e. alkaloids, terpenoids, steroids, flavonoids, carbohydrates, proteins, amino acids, tannins, and phenolic compounds present in them.

The results obtained it is clear that all selected plant extracts show the presence of alkaloids, phenols, and flavonoids, in petroleum ether, extract shows the presence of only fats and oil. Hydroalcoholic extract of A. occidentale, A. marmelos, and A. aspera shows the presence of alkaloids, glycoside, phenols, and flavonoids.

Quantitative analysis is an important tool for the determination of the quantity of phytoconstituents present in plant extracts. For this, TPC and TFC are determined. The hydroalcoholic extract obtained from bark of $A$. occidentale, leaves of $A$. marmelos, and whole aerial plant

Table 6: Total phenolic and flavonoids content of Anacardium occidentale

\begin{tabular}{llll}
\hline S. No. & Plant extracts & $\begin{array}{l}\text { Total phenol } \\
\text { (mg/g) }\end{array}$ & $\begin{array}{l}\text { Total flavonoids } \\
\text { (mg/g) }\end{array}$ \\
\hline 1 & Hydroalcoholic & 0.125 & 0.094 \\
2 & Aqueous & 0.048 & 0.075 \\
\hline
\end{tabular}

Table 7: Total phenolic and flavonoids content of Aegle marmelos

\begin{tabular}{llll}
\hline S. No. & Plant extracts & $\begin{array}{l}\text { Total phenol } \\
\text { (mg/g) }\end{array}$ & $\begin{array}{l}\text { Total flavonoids } \\
\text { (mg/g) }\end{array}$ \\
\hline 1 & Hydro alcoholic & 0.254 & 0.121 \\
2 & Aqueous & 0.121 & 0.095 \\
\hline
\end{tabular}

Table 8: Total phenolic and flavonoids content of Achyranthes aspera

\begin{tabular}{llll}
\hline S. No. & Plant extracts & $\begin{array}{l}\text { Total phenol } \\
\text { (mg/g) }\end{array}$ & $\begin{array}{l}\text { Total flavonoids } \\
\text { (mg/g) }\end{array}$ \\
\hline 1 & Hydro alcoholic & 0.256 & 0.145 \\
2 & Aqueous & 0.110 & 0.075 \\
\hline
\end{tabular}


Table 9: Result of in vitro free RSA

\begin{tabular}{llllll}
\hline \multirow{2}{*}{ Concentration $(\mu \mathrm{g} / \mathrm{mL})$} & Ascorbic acid & & Hydroalcoholic extracts & & \\
\cline { 2 - 2 } \cline { 5 - 6 } & \% inhibition & & Anacardium occidentale & Aegle marmelos & Achyranthes aspera \\
\hline 20 & 92.197 & 58.996 & 78.184 & 87.579 \\
40 & 92.914 & 63.535 & 79.777 & 90.047 \\
60 & 93.789 & 66.321 & 82.882 & 91.082 \\
80 & 96.417 & 71.815 & 84.235 & 92.436 \\
100 & 97.452 & 75.00 & 87.579 & 94.028 \\
\hline
\end{tabular}

material of A. aspera is subjected to estimate the presence of TPC and TFC by standard procedure.

Phenolics play an important role in plant development, particularly in lignin and pigment biosynthesis. They provide structural integrity and scaffolding support to plants. In this study, the higher amount of TPC was recorded in the hydroalcoholic extract of A. occidentale, A. marmelos, and A. aspera $(0.125 \mathrm{mg} / \mathrm{g}, 0.254 \mathrm{mg} / \mathrm{g}$, and $0.256 \mathrm{mg} / \mathrm{g})$ followed by aqueous extract $(0.048 \mathrm{mg} / \mathrm{g}, 0.121 \mathrm{mg} / \mathrm{g}$, and $0.110 \mathrm{mg} / \mathrm{g})$, respectively [13].

Flavonoids play an important role in the protection of plants against plant-feeding insects and herbivores. Their presence can alter the palatability of the plants and reduce their nutritive value, decrease digestibility, or even act as toxins in few cases. The present work shows maximum TFC in the hydroalcoholic extract of $A$. occidentale, A. marmelos, and A. aspera $(0.094 \mathrm{mg} / \mathrm{g}, 0.121 \mathrm{mg} / \mathrm{g}$, and $0.145 \mathrm{mg} / \mathrm{g})$ followed by aqueous extract $(0.075 \mathrm{mg} / \mathrm{g}, 0.095 \mathrm{mg} / \mathrm{g}$, and $0.082 \mathrm{mg} / \mathrm{g})$, respectively.

Antioxidant plays a central role in defusing free radical species which are formed from various biochemical reactions in normal system. These free radicals are the main culprits in lipid peroxidation. The production of reactive oxygen species and free radicals occurs in various diseases, which directly/indirectly activates phagocytic cells. The synthetic medicines are known to produce severe side effects in the body. Phytodrug having antioxidant property is non-toxic or may have minimum side effects than synthetic compounds. The hydroalcoholic extract of $A$. occidentale, A. marmelos, and Achyranthes shows the $\mathrm{IC}_{50}$ value of $125 \mu \mathrm{g} / \mathrm{ml}$, $98.89 \mu \mathrm{g} / \mathrm{ml}$, and $105.58 \mu \mathrm{g} / \mathrm{ml}$, respectively, and $\mathrm{IC}_{50}$ value for standard ascorbic acid was found to be $21.65 \mu \mathrm{g} / \mathrm{ml}$. The antioxidant activity of sample was less than that of standard ascorbic acid [14].

\section{CONCLUSION}

From our studies, the extracts of medicinal plants were investigated for their total antioxidant capacity; the presence of high phenolics and flavonoids content. The high contents of phenolic compounds indicated that these compounds contribute to the strong antioxidant activity. Further studies of this plant species should be directed to carry out in vivo studies of its medicinal active components to prepare natural pharmaceutical products of high value.

\section{AUTHORS' CONTRIBUTIONS}

Sushil Kumar supervised the work; Brijyog and L. P. Singh conducted the experiments and monitored the work progress. Brijyog and Shweta Verma drafted the manuscript for publication. All authors read and approved the final manuscript.

\section{CONFLICTS OF INTEREST}

The authors declare that they have no conflicts of interest, financial, or otherwise.

\section{REFERENCES}

1. Singh PS, Bal M, Mukhtar MH, Shah G. Standardization and pharmacological investigation on leaves of Ficus bengalensis. Int J Res Pharm Chem 2011;1:891-903.

2. Robbers JE, Tyler VE. Tyler's Herbs of Choice: The Therapeutic use of Phytomedicinals. $3^{\text {rd }}$ ed. New York: Haworth Press Inc.; 1999. p. 287-95.

3. Mukherjee PK. Quality Control of Herbal Drugs, an Approach to Evaluation of Botanicals. $1^{\text {st }}$ ed. New Delhi: Business Horizon; 2002. p. 112-25.

4. Kujur RS, Singh V, Ram M, Yadava HN, Singh KK, Kumari S, et al. Antidiabetic activity and phytochemical screening of crude extract of Stevia rebaudiana in alloxan-induced diabetic rats. Pharmacogn Res 2010;2:258-63.

5. Saeed N, Khan MR, Shabbir M. Antioxidant activity, total phenolic and total flavonoid contents of whole plant extracts Torilis leptophylla $\mathrm{L}$. BMC Complement Altern Med 2012;12:221.

6. Mythili K, Reddy CU, Chamundeeswari D, Manna PK. Determination of total phenol, alkaloid, flavonoid and tannin in different extracts of Calanthe triplicata. J Pharmacogn Phytochem 2014;2:40-4.

7. Biju J, Sulaiman CT, Satheesh G, Reddy VR. Total phenolics and flavonoids in selected medicinal plants from Kerala. Int J Pharm Pharm Sci 2014;6:406-8.

8. Kostic DA, Dimitrijevic DS, Mitic SS, Mitic MN, Stojanovic GS, Zivanovic AV. Phenolic content and antioxidant activities of fruit extracts of Morus nigra L (Moraceae) from Southeast Serbia. Trop J Pharm Res 2013;12:105-10.

9. Harborne JB. Phytochemical Methods: A Guide to Modern Techniques of Plant Analysis. Vol. 2. New York: Chapman and Hall; 1984. p. 288-95.

10. Braca A, Sortino C, Politi M, Morelli I, Mendez J. Antioxidant activity of flavonoids from Licania licaniae flora. J Ethnopharmacol 2002;79:379-81

11. Helen LR, Jyothilakshmi M, Latha M. Antioxidant potential and antiproliferative effect on HCT-15cells. Int J Pharm Sci 2015;17:170-5.

12. Ahmad M, Shah AS, Khan RA, Khan FU, Khan NA, Shah MS, et al. Antioxidant and antibacterial activity of crude methanolic extract of Euphorbia prostrata collected from district Bannu (Pakistan). Afr J Pharm Pharmacol 2011;5:1175-8.

13. Ashalatha KS, Reddy AR, Raveesha HR. Evaluation of phytochemical compounds and antimicrobial activities of Hemidesmus indicus. Asian J Pharm Clin Res 2019;12:102-6.

14. Akila B, Manikandaselvi S. In vitro antioxidant and anticancer efficacies of ethanolic fruit extract of Ziziphus jujube mill. Asian $\mathrm{J}$ Pharm Clin Res2019;12:160-5. 